\title{
OPTIMIZING AIRPORT SURFACE OPERATIONS USING DATALINK AND THE TAXIWAY NAVIGATION AND SITUATION AWARENESS (T-NASA) DISPLAY SUITE
}

\author{
Becky L. Hooey ${ }^{1}$, David C. Foyle ${ }^{2}$ Anthony D. Andre ${ }^{3}$, Kevin P. Purcell ${ }^{3}$, and Susan Dowell ${ }^{3}$ \\ ${ }^{1}$ Monterey Technologies, Inc., / NASA Ames Research Center, Moffett Field, CA 94035 \\ ${ }^{2}$ NASA Ames Research Center, ${ }^{3}$ San Jose State University Foundation / NASA Ames Research Center
}

Aircraft taxi operations have been shown to be inefficient and prone to high workload, radio frequency congestion, and communication errors (Kelley \& Adam, 1997). Further, in low-visibility or night taxi conditions, taxi speeds decrease by approximately $20 \%$ and navigation errors increase leaving aircraft prone to traffic incursions (McCann, et al., 1998). To increase the efficiency and safety of surface operations, the Taxiway Navigation and Situation Awareness (T-NASA) cockpit display suite, comprised of an electronic moving map, a scene-linked head-up display, and 3-D audio alerts, was proposed (Foyle, et al., 1996). The T-NASA display suite has been subject to an extensive design and evaluation process (Andre, Hooey, Foyle, \& McCann, 1998; McCann et al, 1998;), however, less is known about issues associated with the implementation of these displays into current and future taxi operations. This study set out to address several operational issues that were identified by pilots and controllers in a series of scenario-based focus groups (Hooey et al., 1999). These issues included the modality, timing, and presentation of taxi clearances and other surface related communications, and the ability for such a system to support time-sensitive and dynamic taxi operations.

\section{PROCEDURE}

Using NASA Ames high fidelity Advanced Concept Flight Simulator, 18 airline crews completed low visibility (RVR 1000 ) land-and-taxi scenarios. Crews taxied current day scenarios using standard operations and equipment (voice communications, ground clearances and Jeppesen chart for navigation) and future operations scenarios with either a Transition or Advanced equipment package (See Table 1). The Transition package, designed to integrate easily into current operations, provided ATC communications by both voice and datalink. The Advanced package, designed to accommodate an expected three-fold increase in airport traffic, provided ATC communications via datalink only, and included advanced features such as airborne taxi clearances.

Table 1. Experimental design
\begin{tabular}{|c|c||c|c|}
\hline & Current Day & \multicolumn{2}{|c|}{ Transition Operations } \\
\hline & Voice, Ground Clearance & Voice + Datalink, & Ground Clearances \\
\hline & No T-NASA & No T-NASA & T-NASA \\
& 4 scenarios & 5 scenarios & 5 scenarios \\
\hline
\end{tabular}

\begin{tabular}{|c|c|c|c|}
\hline & Current Day & Advanc & tions \\
\hline $\mathrm{E}$ & Voice, Ground Clearances & Datalink only, & e Clearances \\
\hline ㅎํㄹ & $\begin{array}{l}\text { No T-NASA } \\
4 \text { scenarios }\end{array}$ & $\begin{array}{l}\text { No T-NASA } \\
5 \text { scenarios }\end{array}$ & $\begin{array}{c}\text { T-NASA } \\
5 \text { scenarios }\end{array}$ \\
\hline
\end{tabular}

\section{RESULTS}

The T-NASA display suite increased taxi speeds by $16 \%$ over current day scenarios $\left(\underline{\mathrm{M}}_{\text {Current }}=13.9 \mathrm{kts}, \underline{\mathrm{M}}_{\text {T-NASA }}=16.1\right.$ kts; $\underline{\mathrm{F}}(2,24)=12.77, \underline{\mathrm{p}}<.0001)$. Simultaneously, T-NASA eliminated major navigation errors (making a wrong turn or failing to turn) which occurred in $20 \%$ of the current day scenarios. This provides strong evidence that T-NASA can increase taxi efficiency and safety.

Further benefits were observed with the Advanced equipment package which issued taxi clearances via datalink and T-NASA while airborne (just outside the outermarker). Currently, pilots stop after clearing the runway in order to receive and verify their taxi clearance. Airborne taxi clearances reduced time stopped after runway turnoff, $\underline{\mathrm{M}}_{\text {Ground }}=7.57 \mathrm{sec}, \underline{\mathrm{M}}_{\text {Airborne }}=.02$ sec.; $\mathrm{t}(8)=2.47, \mathrm{p}<.05$. Although airborne taxi clearances require a change to current day operating procedures, significant time savings may be realized.

Results also provided support for the use of datalink for routine surface operations communications. Issuing initial taxi clearances via datalink reduced workload, frequency congestion, and communication errors. However, one potential concern was revealed with the use of datalink to issue dynamic mid-route hold/proceed instructions. Datalinkonly amendments (without T-NASA) increased the time required to initiate action of the taxi instruction; $\underline{M}_{\text {Current }}=10.77$ sec., $\mathrm{M}_{\text {Datalink }}=24.83$ sec.; $\mathrm{t}(5)=-2.62, \mathrm{p}<.05$. However, coupling datalink with T-NASA eliminated the excess delay and returned action initiation times to current day levels $\left(\underline{\mathrm{M}}_{\text {datalink }+\mathrm{T}-\mathrm{NASA}}=9.58 \mathrm{sec}\right.$. $)$. Datalink communications alone may create unnecessary delays but these delays may be ameliorated when datalink is coupled with T-NASA.

\section{CONCLUSION}

These results clearly demonstrate T-NASA s efficiency and safety benefits for surface operations. Also, taxi efficiency may be further increased by implementing changes to current operating procedures that include airborne taxi clearances and datalink communications. These efficiency gains also translate to reduced brake wear, reduced fuel burn, and faster turn around times of aircraft, which may provide substantial cost savings for airlines.

\section{REFERENCES}

Andre, A.D., Hooey, B. L., Foyle, D. C., and McCann, R. S., (1998). Field evaluation of T-NASA: Taxiway Navigation and Situation Awareness System. IEEE/AIAA Digital Avionics Systems Conference. Seattle, WA.

Hooey, B. L., Schwirzke, M.F., McCauley, M. E., Renfroe, D., Purcell, K., \& Andre, A.D. (1999). Issues in the Procedural Implementation of Low-Visibility Landing and Surface Operations Displays. Proceedings of the $10^{\text {th }}$ International Symposium on Aviation Psychology. Columbus, $\mathrm{OH}$.

Foyle, D. C., Andre, A. D., McCann, R. S., Wenzel, E., Begault, D., \& Battiste, V. (1996). Taxiway Navigation and Situation Awareness (T-NASA) system: Problem, design philosophy, and description of an integrated display suite for low-visibility airport surface operations. SAE Transactions: Journal of Aerospace, $105,1411-1418$

Kelley, D. R., \& Adam, G. L. (1997). The Human Factors of Runway Incursions Caused By Pilot Error: A Survey of U.S. Airline Pilots. In R. S. Jensen and L. A. Rakovan (Eds.), Proceedings of the $9^{\text {th }}$ International Symposium on Aviation Psychology, 911-917. Columbus, OH.

McCann, R.S, Hooey, B.L, Parke, B., Foyle, D.C., Andre, A.D. \& Kanki, B. (1998). An Evaluation of the T-NASA System in High Fidelity Simulation. (Paper 985541) Proceedings of the AIAA/SAE World Aviation Congress. SAE International: Warrendale, PA. 